Haralumbus, M

1997 Sociology Theme and Perspectives, Oxford University Press, Delhi.

Kalpagam, U.

1994

Labour and Gender Surrival in Urban India, Sage Publications, New Delhi.

Keller, Fox Evelyn and Helen E. Lorgino

1996 Feminism and Science, Keller, Fox Evelyn and Helen E. Lorgino Oxford University Press, New York.

Lorber, Judith

1994 Paradoxes of Gender Yale University Press, New Haven and London.

Mair, Lucy

1999

An Introduction to Social Anthropology, Second Edition, Oxford University Press, Delhi.

Pathy, Jagannath

Anthropology of Development Demystifications and Relevance, Gain Publishing House, Delhi.

Seddon, David 1995

Nepal a State of Poverty, Vikas Publishing House Pvt. New Delhi.

Slayter, Barbara Thomas, Andrea

Lee Esser, M. Dale Shields 1993

Tools of Gender Analysis: A Guide to field Methods for Bringing Gender into Sustainable Resource Management, ECOGEN Research Project, International Development Program, Clark University.

Strishakti 1995

Women Development and Democracy, A Draft Report Presented to Danida.

\section{EXCLUSION, THE POLITICS OF LOCATION AND WOMEN'S PROPERTY RIGHTS DEBATES IN NEPAL: A DISCOURSE ANALYSIS OF POLITICAL ACTIVISM}

Youba Raj Luintel*

The issue of women's right to parental property had sparked much controversy since the Bill was first presented in parliament. Advocates of the Bill and women rights groups had taken out a series of demonstrations demanding early passage of the Bill. Activists had gone to the extent of chanting slogans inside the House of Representatives and were thrown out by security personnel. They had even dragged the then Speaker out of his car at Singhadurbar gate. Oplponents of the Bill have claimed that the country at present is not ready for such a move that would bring sisters into property disputes that traditionally is limited to brothers.

- A news report in The Kathmandu Post (September 7; 1999).

\section{The Context}

The relationship between gender and property ${ }^{1}$ is one of the gateways to understand the crux of women's subordination. Women's property status in any society is one critical issue deserving due attention in order to understand the specificities of gender relations in that particular setting. This is, therefore, one of the crucial political arenas of women's empowerment process

* Mr. Youba Raj Luintel is ther Lecturer in Sociology at the Central Department of Sociology/Anthropology, Tribhuvan University, Kirtipur, Kathmandu.

I would like to thank Dr. Saskia Wieringa and Dr. Brigitte Holzner for their comments on an earlier draft of this paper

1 The term "property" refers to all productive resources and assets that a man or woman requires for his/her existence, subsistence and wellbeing. In the agrarian economies of South Asia arable land is the most valued form of property for its economic as well as political and symbolic significance (Agarwal, 1999). In this paper, however, property has been defined in a broader perspective, so we do not focus only on land. 
A struggle for gender equality in command over property, therefore, needs to occupy a central space in women's struggle for egalitarian gender relations (Agarwal, 1999). In Nepal, a daughter does not have a full inheritance right over property. It is in this context that women's movement during and after 1990s has focussed its central attention on women's equal rights to property.

The Constitution of the Kingdom of Nepal guarantees equal rights to property for both men and women. In 1990, Nepal has ratified the Convention on the Elimination of All Forms of Discrimination Against Women (CEDAW) without any reservation. The country has also accepted the 12-point program formulated in the fourth women's conference in Beijing. Hence both national and international legal tools bind Nepal for ensuring that women along with men will have access to and control over productive resources including land without any discrimination for one gender against another. However, in practice, this has never been materialized. The conservative Civil Code, called the Muluki Ain, 2020 (1963 AD), does not allow a daughter to have a full (property) inheritance rights. For example, a daughter's rights to inherit property have been secured only if she remains unmarried till the age of 35 years, a phenomenon rare in Nepal. ${ }^{2}$ In case she gets married later on, she must return the share (NPC, 1997). A married woman is recognised not as an independent citizen but as a co-parcener to her husband, she, therefore, cannot claim a share over the property "in his lifetime" (Malla, 1998).

In exceptional conditions such as polygamy, cruelty or denial to provide foods and other essential requirements, she has a right to ask for her share in property. Still there are several barriers. First, the so-called "essential requirements" have

2 Since late marriage or non-marriage are a rare phenomenon in Nepal, due to social discouragement or stigmatization attached on it, and since the concept of single mother is culturally very alien, not only that marriage is near universal, but also the age at marriage is quite low. The legally sanctioned minimum age at marriage is 16 years for the girls and 18 years for the boys. The census data (1991) show that about 63.2 percent women of the age 10 years and above are married (CBS, 1993:97) nowhere defined in the Muluki Ain. There is a scope for casespecific manipulation. Second, to be entitled for a claim on property, it must be at least 15 years of marriage. Third, a divorcee even cannot claim a share in property from either husband or her father side. She will be provided a "maintenance cost" up to a period of five years from the date of divorce (FWLD, 1999a). Fourth, a widow at her age less than 30 years and without a son (even daughter is not mentioned) is neither entitled to take a share in property nor to live separately. Finally, even for the tenancy rights, an unmarried daughter and/or widow daughter-in-law should cross 35 years of age (NPC, 1997).

This paper has relatively a narrow focus. It looks at the ongoing struggle for and the debate on women's property rights ${ }^{3}$ in Nepal. I would attempt to approach the issue from the perspective of the post-modernist feminism. I first problematise the issue of women's property rights in Nepal. Drawing some of the theoretical concepts on public sphere, exclusion, power and discourse, I would outline an analytical framework to look at the issue as a form of exclusion. I argue that negation to women's property rights issue at its various levels has a socio-political and ideological embeddedness at the very configuration of Nepalese society that is overtly patriarchal. I also argue that pending of the bill on women's property rights in the parliament for the last four years is one of the manifestations of this patriarchal embeddedness. So long as this patriarchal embeddeness is not deconstructed, just challenging it will never bring a substantial change in gender relations, irrespective of the fact of the approval of the bill by the parliament in the near future.

\section{Framework of Analysis}

Public sphere is a space of civil society where citizens deliberate their common affairs. It is a site of production and circulation of discourses that can be critical to the state (Fraser, 1995). For liberalists, public sphere means a space or issue which is state related, accessible to everybody, of concern to

\footnotetext{
3 By "property rights" we mean men's and women's institutional access to and control over the productive resources and assets. This is something more than a legal recognition to claim over property.
} 
everyone, having common goal and shared interests (Fraser, 1995). For them, sexuality, private property and such other familiased and personalised issues fall outside the realm of public sphere. Post-modernist feminists are, however, critical to such essentialist divide. Accordingly, there is no natural or a priori boundaries between so-called publicity and privacy (Fraser, 1995). The rhetoric of domestic privacy tends just to exclude some issues and interests from the debate. For public sphere to be effective, social inequality should be removed. On top of that, not exclusion but inclusion, not inadmission but admission of issues and interests (of women) should be ensured. Fraser notes three counter-assumptions against liberal conception of public sphere:

- first, acknowledgement that participation parity requires not merely bracketing but elimination of social inequality;

- secondly, multiplicity of mutually contestatory publics. For the post-modernists, there cannot be a single public sphere, there should be parallel discursive arenas, called "subaltern counterpublics;" ${ }^{4}$ and

- finally, inclusion and admission of those issues and interests that were excluded or not admitted before (Fraser, 1995:291, 295)

Jodi Dean (1996) categorically describes how are women's issues and interests excluded form public sphere. She distinguishes two kinds of exclusion: practical and constitutive. Institutional (such as legal) and cultural (interpretative) barriers cause to practical exclusion. Such exclusion prevents some of the issues as sexuality, childcare, domestic violence, property rights, etc. from entering into political debate. Women's functional position in the household, and their reproductive (biological) characteristics are projected as pretensions to block their involvement in public places. These are practical forms of exclusion.

4 "Subaltern counterpublics," Fraser says, emerge in response to exclusions within the dominant public, when members of subordinated social groups repeatedly feel it advantageous to constitute alternative publics. They are parallel discursive arenas where members of such groups reproduce and circulate counter-discourses (Fraser, 1996:291)
On the contrary, constitutive exclusion refers to the notion that publicity, justice and rationality are male attributes while that of privacy, the good life and emotionality are female attributes (Dean, 1996). The distinction of public-private itself is based on the male gaze and the masculine experiences. These conceptions cannot serve as ideals for women. So long as such distinction persists women have to conform a set of masculine standards in order to participate in the public life. Therefore, a theory of civil society that includes women, argues Dean (1996), cannot be based on a distinction between the public and private. It must be reformed to allow for the expansion of "communicative rationality" that would allow multiple, interconnecting and discursive spheres.

Once we accept that there should be multiple public spheres (see fn.6), and that the exclusive and oppressive publicprivate divide cannot serve the specific and particularistic needs and interests of women, we then challenge the dominant power discourse that surrounds us. Foucault argues that power is not imposed from the top of a social hierarchy, nor is it derived from a fundamental opposition between rulers and the ruled. For him, power is relational, that operates in "capillary fashion" from below (Pringle and Watson, 1992). Power finds a shifting and unstable expression in networks and alliances that permeates every aspect of life (Pringle and Watson, 1992:55).

It is also said that there has been a relational, historical and precarious character of realities ${ }^{5}$ (Pringle and Watson, 1992:64). Identities are constituted in language while subjectivities are produced through discursive practices. Hence, it is discourse that constitutes reality. Pringle and Watson conclude, "(i)n post-structuralist account of state, 'discourse' and 'subjectivity' rather than structures and interests become the key terms" (1992:65).

\footnotetext{
5 Postmodernists refuse to accept that there is the (a single) reality. There are in fact multiple realities: one that is a true reality for one may not be the same for another. So realities are a social construction, an output of discourse and knowledge. All discourses and knowledge production have been a masculine business. Therefore, women must deconstruct all forms of (masculine) realities at their respective levels and produce counterrealities, called the "subaltern counterpublics."
} 
Such a notion of power and reality has multiple implications so far as feminism is concerned (Pringle and Watson, 1992). First, state is not accepted as a unified reality but is challenged as a byproduct of struggles. Secondly, once we accept that power is produced and derived from discursive practices, thereby, we recognize that we ourselves can deconstruct and reconstruct power. Finally, it is also accepted that we can assert our agency, articulate our voice, and create our subjectivities.

But there exist some ambiguities that call for a due attention. The traditional basis of feminist solidarity does not exist now. (The so-called global sisterhood based on the white, heterosexual, bourgeoisie and middle class woman has been challenged severely.) There is no identified feminine "we" and masculine "they" (Mohanty, 1995). When we do not have a single voice, a common interest and a shared identity, how can then we create a sisterhood? It is in this context that postmodern feminists argue for a politics of difference. It is accepted that since we are not only embodied but also embedded in our contexts, there is no universal sameness, no automatic affinity, and no ontological unity. Instead of seeking artificial sameness and common affinity, we recognise our differences. Once we accept differences, it can be a basis for a further negotiation. This is what Mohanty $(1995: 68)$ called the "politics of location." This kind of politics reflects our differences. Therefore, our new solidarity will be a "reflective solidarity," our coalition will be a "rainbow coalition."

\section{Women's Property Rights Discourse in Nepal}

For a long, gender discrimination regarding women's property rights did not bring notable resistance at the public level. It is with a petition filed by a (female) lawyer that it challenged many laws (including the Muluki Ain) as

${ }^{6}$ Phillips quotes Iris Young as referring to the American idea of "rainbow coalition" based on "heterogeneous publics" in which groups can work together but retain their identity. Groups' identity should not be swallowed up in a unified approach for the "rainbow coalition" (Phillips,1991:83-84). discriminatory against women. ${ }^{7}$ In 1995 , the Supreme Court gave a verdict declaring that i) the existing provisions to inherit parental property are "conditional" for daughter [so are discriminatory against them], ii) the government should within a year introduce a bill reviewing all the laws related to property rights (Malla, 1998). Although the decision of the Court was not so straight forward, still it insisted a heavy controversy, enormous debates and strong reactions, explicit or implicit, from every walk of life. It gained not only wider support but also insisted mass protests and counter-arguments. What the Supreme Court verdict eventually contributed is: first, it helped diffuse the debate from an elite circle of politicians and academia to a wider civil society; and second, it created a strong and vibrant solidarity and networking among the feminist activists and women's organizations to safeguard the "little achievement." Women's organizations up to the date were split into ideological and other differences so much that the movement itself was very weak and indecisive ${ }^{8}$ (Shrestha, 1998). Meanwhile, as a result of pressures from NGOs, donor community, and activist women's organizations, as a fulfillment of its commitment during the

7 The case is popularly known as "Meera's case," since Meera Dhungana, a female lawyer, filed it in the Supreme Court (see Nepal Law Journal, 1994).

8 Here I would like to cite the creation of Women's Security Pressure Group (WSPG) that vividly reflects the point. As an immediate response to incidents of increased rape and other forms of violence against women, just after the introduction of democracy in the country, the WSPG was developed as a network of 96 women's organizations and NGOs on an ad hoc basis. Immediately, it became such an effective forum that it made fulfilled a need of a consolidated political movement of Nepalese women. Quickly after its formation - led my women's wings of two rival parties (Nepali Congress and the Communist Party of Nepal, UML) -- WSPG became an integral part of women's movement with much more vigour and recognition. Now WSPG's exclusive concentration goes on women's property rights issue through awareness campaigns, demonstrations, public discussions, political activism, etc. For a detail discussion on WSPG see Shrestha (1998) 
parliament election government introduced the Civil Code, 1963 (the Eleventh Amendment) Bill, 1997 in the parliament. ${ }^{9}$

While the bill was under the consideration of the Human Rights Committee of the parliament before going to a discussion in the full house,$^{10}$ unfortunately, on 15 January 1999 the House of Representatives was dissolved (due to other political reasons). Consequently, the legal status of the bill was lapsed (Pro-Public, 1995:30). Despite the fact that a new government of Nepali Congress with a clear majority in the parliament was formed after the mid-term election (1999), the government did not show its immediate interest to revive the pending bill. The highly contested bill has been registered in the parliament second time in $2000 .^{11}$ However, since the subsequent $19^{\text {th }}$ session of the parliament has been in a standstill situation due to power tussle between the ruling and opposition parties, there is very little hope that the property rights bill will be under discussion and consideration during this session.

Besides parliament, the Supreme Court decision also faced a wider response from men and women from all walks of life. Several NGOs, activist women's organisations, women's wings of political parties, professional organisations and the mass media equally get involved in the debate. Primarily their focus has been either to raise awareness towards property rights

9 The bill -- prepared by the Ministry of Law and Justice (MLJ) -- was registered on 31 July 1997 in the parliament during its $16^{\text {th }}$ session (Malla, 1998). The government did not consider a fresh draft prepared by the Ministry of Women and Social Welfare (MWSW). It reflects the contradictions inherently built within government system on issues like this.

${ }^{10}$ The controversial bill had stirred debate between women rights groups and the parliamentarians. A series of protests by the activists on the one hand and over 150 applications for amendment to the proposed bill delayed voting and adoption of the bill as law (see The Kathmandu Post, 17 July 1999).

11 This time, the parliamentary Law, Justice and Parliamentary Affairs Committee has been busy seeking suggestions and information on the controversial bill. Members of the committee had travelled to all the 14 zones to collect suggestions so that the voices of the common people to the intellectuals were included in the bill. This was the first time that such a massive job had been undertaken to solicit suggestions from the grassroots, that is effected the most, by these laws. (The Kathmandu Post, 9 February 2001). issue and create public pressure on government to implement the verdict of the Court earlier or to oppose it and make an antiproperty rights sentiment. To draw a glimpse of this debate, below I would cite some of the prominent issues that have been surfaced. To bring the discussion within the scope of this paper I would confine myself in two sources: the first is based on the findings of a field survey (see FWLD, 1999b), and the other is based on a seminar discussion (see Dali, 1997).

A field study conducted by the Forum for Women, Law and Development (FWLD) reveals that of the total respondents, only 30 per cent felt that a new bill ensuring women's inheritance rights should be introduced (FWLD, 1999b:18). Fifty-five per cent of the respondents surveyed were in favour of a "will system" (that is, rights to property based on parents' will), followed by 15 per cent who were supporting very much the existing system of property inheritance (FWLD, 1999b). The study shows that majority of the respondents are in favour to change existing inheritance system. It is ironic, however, that they are not willing to allow women to inherit property. The respondents perceived the following consequences that a system of equal property rights might bring:

- problem of land fragmentation and management; ${ }^{12}$

- no guarantee that the husbands would not misuse their wives' property;

- equal access to education, employment and opportunity as more important than rights to property;

- in a country where a majority of households is below the poverty line, equal property rights to women is not a meaningful question;

- trouble to the elderly and the disabled parents (because the daughters also will take the property but it will be son alone who will have to take care of the parents, etc.).

12 The similar argument appears elsewhere in South Asia. According to Agarwal (1999:284), patrilocal marriages in distant villages make it difficult for women to directly supervise or cultivate land they may inherit in natal village. 
Likewise, a seminar organised for the intellectuals and professionals by a women's publication house also brought more negative than positive arguments (Dali, 1997). Some of them are:

- devaluation of daughter. (Not their proclivity and "beauty" but property becoming valued);

- out-flight of property to India due to inter-boarder marriages. (In the case of Northern India which boarders Nepal there is no property rights to women);

- encouragement for men and women living single;

- encouragement of son preference in the society. Promotion of sex-selective abortion and/or infanticide of female child (because daughters will be seen as economic burden);

- increased rate of divorce, family break-ups and problems of broken home children;

- hardship for poor girls to find partners, therefore increased anxiety, stress and depression to them, etc. (Dali, 1997).

Through these arguments both common people and intellectuals show that they are still reluctant to allow women to have equal property rights. In a recent news-report, for example, one of the (female) members of parliament was quoted as saying that issue of property rights was not suitable to her society. ${ }^{13}$ Another newspaper reports that the then Minister of Law and Justice was ridiculed by women's activists at a talk program when he did not favour the property rights issue. ${ }^{14}$ Likewise, the Chief Justice was quoted in a news who argued that both son and

${ }^{13}$ Ms Renu Yadav, Member of Parliament, was quoted in a news report saying, "we have typical reality in our village [of Terai]. It's not yet a high time to provide women property rights. First, we should make the rural women at the grassroots level fully aware, only then we can think on it" (Shrestha, 2000).

14 Taranath Ranabhat, the then Minister of Law and Justice said: "The movement to bring forth equal property rights (to women) is just superficial; to really achieve the 'equality of right' the activists would have to reach the grassroots level...Law can be enforced any time but that would not be practiced and hence would not serve the purpose ("Women rights activists ridicule law minister," The Kathmandu Post, 3 June 1999). daughter should not be given any legal right to inherit parental property - implying that the will system should be introduced (The Kathmandu Post's editorial, 4 November 1999).

All these expressions clearly reveal patriarchal reluctance, ambivalence and social contradictions embedded in the Nepalese society at large. Nevertheless, issue of women's property rights has grasped momentum and the campaign has already appeared as a part of vibrant civil society movement. In the section that follows it, I would attempt to look at the issue through the lens of some concepts summarised earlier in this paper.

\section{Denial to Property Rights as a Form of Exclusion ${ }^{15}$}

Nepalese women are deprived of many rights including basic citizenship rights. ${ }^{16}$ They are recognised not as political citizens but as "altruist citizens" (see Philips, 1991). Their citizenship is devoid of political nature at the cost of mothering, morality and civic virtue. Since the political-ideological configuration of Nepali society at the macro level is very much influenced by modern and liberal school of thought, the discourse of fraternity predominates all discourses.

As a result, a large segment of population still thinks that sexuality and property issues are private issues, in which state is not supposed to intervene. Intra-familial debates in property and sexuality are so detached from public concerns that even close community and neighbours are supposed not to respond to in anyway. Since men have exclusive and monopoly command over household property, and wives' sexuality, women's position has always been characterised by economic and emotional subordination. When we look at this issue from Fraser's standpoint (1995:295), we can find three distinct features:

15 According to Kabeer (2000), economic exploitation, marginalization and deprivation are the three basic forms of economic exclusion.

${ }^{16}$ For instance, Nepalese women can get citizenship only through father or in the married case through husband. She cannot register her newly bom baby on her name, without showing a social father. She should produce permission from her (male) "guardian" to apply for a passport, etc. 
- There is economic inequality between men and women, which is considered as "natural" under liberal fraternal discourse.

- Economic activities have been largely an androcentric activity that has always marginalised women's economic needs and rights.

- Women's economic issues and interests are excluded and treated as "inadmissible" into the dominant public sphere.

Following Dean's framework (1996) of exclusion, we can see three forms of economic exclusion of Nepalese women from both mainstream economic activity as well as discourse.

First, there are certain "situational obstacles" that restrict Nepalese women from entering into public economic institutions. The existing legal barriers clearly restrict them from having rights over property. The Civil Code, 1963, discussed above in this paper (see section 1.0), is a buming example as a discriminatory legal mechanism that does not recognise women as bona fide citizen to have rights over property. Efforts to amend it have created tremendous debate and controversy in and around the Supreme Court, the parliament and feminist organisations. This is an instance of exclusion of women's interest in a weak sense of the term, because it is based on traditional legal barrier(s).

Secondly, women's inclusion in property system has been paralysed due also to cultural and religious orthodoxy. Being a Hindu Kingdom, the juridical-ideological make up of Nepali society is primarily masculine. ${ }^{17}$ As a reflection of it in the daily life of common people, every male is supposed to be the procreator and protector of female and femininity. On the contrary, women are always posited as "satisfiers" to "male

${ }^{17}$ Hinduism is a body of cults and sects that commonly appreciates phallic power. The cult of linga puja (literally "worshipping penis"), for example, is a clear manifestation of phallo-logocentrism of Nepali society. Male and female devotees worship linga (penis-like image), which is supposed to represent the real penis of Mahadeva, the god of the destruction. This shows the symbolic and ideological bias of Nepalese society underpinned at patriarchal values. needs" in terms of food, pleasure and sex. "Men produce, women cook" is the mythical social ideal. Logically, those who "produce" also own the required resources and have command over them. This is the cultural interpretation of economic inequality along the gender lines. In this sense, it is women's exclusion in its strong sense.

Thirdly, there is something inherent within Nepali society itself that prevents women's full inclusion in the property system. The very conceptualisation of male as "breadwinner" and "head" of the household, while female as domestic "supporter" operates at the conceptual-theoretical level. This clearly marks the public-private divide of social sphere. Given the strong control over women's autonomy in terms of mobility, sexuality, reproduction, and gender division of labour, women are absolutely confined to domestic sphere, a sphere that is unrecognised and undervalued. Under this ideology, women are not recognised as subjects deserving property entitlement so long as they are under "male protection." Hence, it constitutively excludes women from enjoying full citizenship rights to own, inherit and control property among other things.

\section{Politics of Location: Creating Space through Counterdiscourse:}

"Two decades ago, the question: 'Do women need independent rights in land?' was not admitted in public policy discourse in most part of South Asia. Today the question is admissible, but the discussion on it is limited and the answers to it disputed."

-Bina Agarwal (1998:2)

Lack of ownership and control over productive resources is a constraint for Nepalese women through which they have been suffering the most. They are deprived of not only command and control over property but also access to it. A socially recognised form of women's property is only daijo and pewa ${ }^{18}$ in

${ }^{18}$ Daijo refers to a package of gifts from maternal and paternal relatives that they give it in or after marriage to the bride. Pewa comprises of self-acquired property by a woman before her marriage plus gifts from in-laws after marriage. They are, however, not property in its real sense. They have a symbolic value than any economic viability. 
which they have a relative autonomy, but not complete freedom. Its economic potential, however, is so limited that daijo and pewa cannot ensure them from any economic vulnerability.

Until recently planners and policy makers in Nepal, as elsewhere, used to think that woman's economic needs can be accommodated adequately within the household. However, counterdiscourse on women's property rights that Nepalese women did create over the years has successfully challenged this notion. It is through this challenge that, women's property rights issue has begun to receive a minimum space within legislative, executive and judicial institutions in Nepal.

Nepalese women have created a counterdiscourse on their property rights through simultaneous and vigorous efforts in many fronts. They initiated an alternative dialogue through programmes such as "meet the rural women," legal literacy, and political activism at the grassroots. At the center, they concentrated their efforts in challenging the discriminatory laws (such as the Civil Code, 1963) in the court. They also tried to sensitise journalists and other professionals. They got involved in lobbying with international donor agencies such as the World Bank, the Asian Bank, USAID, etc.

Alternatively, through a series of mass demonstration, they asserted a kind of moral pressure on the government and political parties to respond to the issue. Now it has become a ritual for each new government to renew its political commitment that it will table the Civil Code amendment bill to ensure women's equal property rights in the parliament. It is a reflection that the official economic discourse has recognised the validity of the issue. Property rights issue has also become one important agenda for political parties during at least in the elections. It has become a means to demonstrate their "progressive" face by mentioning it in their manifestos. While there comes the time to materialize this commitment, all of them show a massive scale of reluctance.

An equally important development associated with property rights campaign is that great many women's organisations are involved in building coalitions and creating networks. Existence of several coalitions and networks reveals that women's movement in Nepal has learnt how to situate its campaign based on their political location and politics of differences. It is in this point that I would like to mention WSPG once again (see fn. 6 also). It is a network of 96 women's organisations: some are political others social, some are community-based voluntary organizations, etc. They came into dialogue for a common cause, recognised their political and ideological differences, and accepted it as a basis for negotiation. The WSPG has now become a pride for the activist women. I would, therefore, argue that WSPG is a "rainbow coalition" that represents the common interests of Nepalese women. It has created a sense of solidarity - the "reflective solidarity"- among them that would make certain change in a near future. It would, I hope, deconstruct the oppressive public sphere that has constitutively excluded Nepalese women, their needs and interests from entering into the mainstream deliberation.

Finally, I would like to make a point of caution to women's organizations that they are giving excessive attention on property rights issue, as if it is the only cause of female subordination. I argue that excessive dependence on single agenda of political activism might be strategically counterproductive in the long run. Even in the West, during the suffragist movement of 1960 s and 1970 s, women's economic independence was one of the highly contested terrains propagated much by the liberalists. After its promulgation, however, what they realized was that economic independence alone was a very insufficient cause so far as bringing meaningful change in women's livelihood was concerned. It has to be viewed from two parallel fronts: First, that economy has a political embeddedness. It implies that property rights to women will have a limited potential of women's empowerment within the patriarchal social structure (a lesson that socialist feminists learnt). Second, that right to inherit property will have differential meanings for those who own property and those who do not (a lesson that liberal feminists learnt in Europe and in the USA). Women's activism in Nepal should be aware of those limitations of women's property rights movement. 


\section{REFERENCES}

$1999 b$

Agarwal, Bina

1999

Gender, Property, and Land Rights: Bridging a Critical Gap in Economic Analysis and Policy," in Out of the margins, London, pp.264-289.

Agarwal, Bina

1998 A Field of One's Own: Gender and Land Rights in South Asia, Cambridge: Cambridge University Press.

Anonymous

1993

"Meera Dhungana vs. Ministry Of Law and Justice," Nepal Law Journal, Kathmandu, pp. 462-468.

Bista, Dor B

1991

Fatalism and Development: Nepal's Struggle for Modernization, Calcutta: Orient Longman.

Central Bureau of Statistics (CBS)

$1993 \quad$ Population Census- 1991 (National Volume),

Kathmandu: CBS, National Planning Commission.

Dali, Indira (ed.)

1997

"Women's Property Rights: Role of the Media and an Aspect of the Independent Status." Proceedings of a Seminar, Kathmandu: Asmita Women's Publication House.

Dean, Jodi 1996

"Including Women: the Consequences and Side Effects of Feminist Critiques to Civil Society," in Solidarity of Strangers: Feminism after Identity Politics, Berkeley etc.: University of California Press, pp. 75-101

Forum for Women, Law and

Development (FWLD)

1999a Shadow Report on the Initial Report of the Government of Nepal on CEDAW, Kathmandu: FWLD.

1995

Facilitating the Fulfillment of State Obligation toward Women's Inheritance Right in Nepal. An unpublished report submitted to INRAW Asia Pacific

Fraser, Nancy

"Politics, Culture and Public Sphere: Towards a Postmodern Conception," in L. Nicholson and S. Seldman (eds.) Your Body, Social Postmodernism, Beyond Identity Politics, Cambridge: Cambridge University Press, pp. 286-311.

Kabeer, Naila 2000

Malla, Sapana P 1998

Mohanty, C. Thalpade

"Social Exclusion, Poverty and Discrimination: Towards an Analytical Framework," A paper presented at research seminar at the Institute of Social Studies, The Hague.

Convention on the Elimination of All Forms of Discrimination Against Women (CEDAW) Impact Study, Nepal. A report submitted to the Centre for Feminist Research, York University.

1995 "Feminist Encounters: Locating the Politics of Experience," in L. Nicholson and S. Seldman (eds.) Your Body, Social Postmodernism, Beyond Identity Politics, Cambridge: Cambridge University Press, pp. 68-86.

National Planning Commission (NPC)

1997 United Nations Convention on the Elimination of All Forms of Discrimination Against Women (CEDAW): Initial report, Nepal, Kathmandu: NPC.

Phillips, Anne 1991

"Citizenship and Feminist Theory," in G. Andrews (ed.) Citizenship, London: Lawrence and Wisart, pp. 76-87.

Pringle, R. and S. Watson

1996
"'Women's Interests' and the Post-structuralist State," in M. Barrett and A. Phillips (eds.) Destabilizing Theory: Contemporary Feminist Debates, Cambridge: Polity Press, pp. 53-73. 
Pro-Public

1995

\begin{abstract}
A Survey on Political Rights and Discriminatory Legal Provisions Against Women. An unpublished report, Kathmandu.
\end{abstract}

Shrestha, Sarika

2000

"Where did property rights bill get lost?" Dristi, 11 April2000.(http://www.nepalnews.com.np/con...dri sti/2000/apr/apr11/local.htm)

Shrestha, Shanta L.

1997 "Women's Movement in Nepal," Reflections, summer issue, pp. 21-25.

United Nations Fund for the

Development of Women (UNIFEM)

$1995 \quad$ Mainstreaming Gender Consideration into National Development: Nepal (Final Report), Kathmandu: UNIFEM.

\section{THE SOCIAL WORLD OF NEPALESE WOMEN}

\author{
Dr. Samira Luitel ${ }^{*}$
}

\section{Introduction}

The social situation of Nepalese women is complex and cannot be explained with a single paradigm. The differences are demarcated by the geographical region, economic situation, cultural and caste variations. However, the position of a woman in a family is a determining factor to decide her status in that family in particular, and in the society in general. Thus, the social world of a woman is the picture of her position in each household. To make it clear-the mother, mother-in-law, daughter, daughter-in-law, sister, sister-in-law, etc. have their particular roles and responsibilities and enjoy different status in their particular family. All the women play their roles associated with a particular relation to each individual. Thus a single woman would be playing multiple roles relevant to the relation with the particular individual. There might be individual differences but in general it is learnt or is taught by the system through the process of socialization. One can observe the world of women and men quite distinguished and different rather complete in itself that emphasizes in maintaining the patriarchal values of domination and subordination where some are seen more powerful than the others. Although it is very difficult and also problematic to explain and assess the social status of women from a single perspective, it is also important to look at the relationship among women within the household to see how their single world looks like. I have tried to sketch here how these relationships among women have played roles in creating the subordinate position of women and have victimized a large number of enthusiastic and creative women in return.

* Dr. Samira Luitel is the Lecturer in Sociology at the Central Department of Sociology and Anthropology, Tribhuvan University. Kirtipur, Kathmandu. 